\title{
THE CONCEPT OF TRANSFORMATION OF THE NATIONAL INSTITUTIONAL ENVIRONMENT OF SMALL AND MEDIUM-SIZED ENTERPRISES
}

\author{
Tetiana STROIKO', Dmytro DUSHEYKO² \\ Mykolaiv National University named after V.O. Suhomlynskiy, Ukraine
}

\begin{abstract}
The aim of the article is an attempt to ground the concept of transformation of national institutional environment as the prerequisites for forming of prosperous class of small and medium-sized enterprises. Institutional analysis considers the interaction on the level of individuals and divides a market transaction into transactions (institutional agreements), estimating their value with the help of transaction costs. We conducted a systematization of the notion that brings the institutional environment to the aggregate of norms, regulations, agreements, rules of the game. For the quality assessment of institutional environment on the macrolevel, direct indicators of its assessment were used - quality indexes in international ratings and activities of specialized institutional researches. Practical significance. In the result the quality of the institutional environment of the assessment of The Global Competitiveness Index is extremely low and needs a systematic increase. Values of indicators of a pillar "Institutions" of The Global Competitiveness Index should be a guiding line for development and introduction of state economic policy. An important line of investigations of development mechanism's improvement and regulatory policy's conducting is the institutional environment conception that combines the notions of institute, institutional agreements and transaction costs. A model of institutional environment allows determining of the regulatory policy as a policy that changes elements of institutional environment - institutions, displays in changes of transaction costs. It is grounded that a state apparatus consciously sets as an object the increase of socio-economic role of the entrepreneurship through the creating of favourable conditions of its functioning; a way of this object's achievement is the regulatory policy, efficiency criterion of which is the improving of national institutional environment's quality that is measured by reducing of transaction costs of entrepreneurship subjects. All stated above allows describing the mechanism of regulatory policy in the field of entrepreneurship as a logical order. Measures of regulatory policy influence the quality of institutional environment that leads to the change in transaction costs' value related to its use. A schematic model of modern institutional environment is developed. In accordance with the rules of methodological individualization, subjects of institutional economic relations are separate entities, individuals. Subjects implement among themselves standard institutional agreements, which are presented by lines ("tracks"). These "tracks" necessarily go through formal and informal institutions. Conclusion of institutional agreements is the choice among the institutional alternatives, discrete choice and transaction performance. Some institutions (both formal and informal) can be not involved into conclusion of institutional agreements, thus it is the question of institutions market - subjects' possibility to choose institutions for interaction. Subjects can conclude institutional agreements within the framework of company or state (hierarchies of institutions with certain cruelty) or within the framework of market (relatively soft institution). An important socio-economic role of small and medium-sized enterprises must be confirmed by effective public policy with its support and development. Institutional economic analysis provides the possibilities of qualitative research of problems of small and medium-sized enterprises, developments and introduction of regulatory police, determining of the criteria of its efficiency. The use of system model of institutional environment and principle of methodological individualism allows considering the economic interaction between representatives of small and medium-sized enterprises and state. An increase of institutional environment quality is the main task of regulatory policy. The quality of Ukrainian institutional environment by the criteria of international rating
\end{abstract}

\footnotetext{
Corresponding author:

${ }^{1}$ Department of International Economy and Management of Education, Mykolaiv National University named after V.O. Suhomlynskiy. E-mail: tstrojko@yandex.ru

${ }^{2}$ Department of International Economy and Management of Education, Mykolaiv National University named after V.O. Suhomlynskiy. E-mail: d_dusheyko@ukr.net
} 
Doing Business in comparison with the leading countries during 2007-2013 not exceeded 27\%. A criterion of regulatory policy effectiveness in the model of institutional environment is a cheapening of institutional agreements, i.e. transaction costs decrease that leads to increase of socio-economic effectiveness of small and medium-sized enterprises.

Key words: institutional environment, regulatory policy, entrepreneurship, transaction costs, effective public policy.

JEL Classification: A20, B 22, B41

\section{Introduction}

Development of small and medium-sized enterprises is a priority economical task for societies that have long-term strategies of socio-economic development. An effective inclusion of entrepreneurship's subjects in economic process is determined by regulatory policy in this field and forming of favourable institutional environment. Development and state support of small and mediumsized enterprises is the most important prerequisite for forming of rich middle class, which is exactly the source of economical and political stability in the society, a significant generator of tax proceeds, main consumer and manufacturer of material as well as educational, cultural, scientific benefits. In economies, which succeed to create prosperous middle class based on the entrepreneurship development, many questions are solved successfully in the following areas: employment, productivity of labour, formation and conduction of policy, innovative development, persistence to macroeconomic instability.

In conceptual aspect a question about interaction of business and state is one of the most important and fundamental in the history of economic science. There is a contradiction between the importance, declared by state, of entrepreneurship development through the regulatory policy, which should improve business climate, and the actual regulatory squeeze on business.

Thus, contradictions between high socio-economic importance of entrepreneurship development to build an effective community and squeeze on entrepreneurs in current Ukrainian situation require a search of new theoretic and methodological approaches, conceptions, models as well as drastic changes in public policy in this field.

In the paper attempted to ground the concept of national institutional environment transformation as prerequisites for forming of rich class of small and medium-sized enterprises.

\section{Institutional environment: essence and assessment methods}

In models of neoclassical economics the interaction of subjects takes place in markets of resources and goods; measure unit of interaction are market transaction and its price. Institutional analysis considers the interaction on the level of individuals and divides a market transaction into transactions (institutional agreements), estimating their value with the help of transaction costs. If in neoclassical models the prerequisites for market interaction are the market with complete information, and agents have unlimited possibilities for search of optimal variants of exchange, in institutional models an economic interaction takes place by means of choice of standard kinds of behaviour out of a limited set, i.e. economic behaviour is regulated by "rules of the game".

Rules of economic interaction in institutional economy are described by means of concept of institutional environment. The concept of institutional environment is important in modern institutional economy, at the same time its unanimous definition and sense are absent. The most popular are definitions of institutional environment given by $\mathrm{O}$. Williamson "rules of the game, which means a context in which an economic activity is taken place" (Williamson, 1996) and D. Nort "set of fundamental political, social and juridical rules, which form a basis for production, exchange and distribution" (Nort, 2000).

It should be noted that definitions given above bring the institutional environment to the set of norms, regulations, agreements, rules of the game. But the essence of this environment is a set of institutions, which is displayed in its name. Institution - is a social norm in combination with external enforcement mechanism of its performance (Auzan, 2005).

Task of quality assessment of institutional environment has two main levels: microlevel and macrolevel. On the microlevel it adds up to Regulatory Impact Assessment (RIA) of a concrete institution (norm) or set of institutions contained in one regulatory act. The task of assessment on microlevel is formed in the following way: how introduction or alteration of institution (or regulatory act) would change expenses on its use (transaction costs)? In this question the following aspects can be singled out: positive - assessment of existing institution, regulatory act, and normative - predictive estimate of consequences of alteration, substitution or introduction of a new institute.

On the macrolevel the task of quality assessment of institutional environment has a positive aspect, in which it formulating as task of quality assessment of business climate. Such a task is solving by means of comparison of quality indicators of national institutional environment (various indexes) and such indicators of other countries.

For the quality assessment of the institutional environment on the macrolevel direct and indirect indicators of its assessment are used. Direct indicators of assessment - quality indexes in international ratings and indicators of specialized institutional researches, indirect - development and performance indicators of economic 
system, in particular, small and medium-sized enterprises.

Positive analysis of the quality of institutional environment lies in research of the current state with an international or retrospective comparison. In the normative area the task of assessing the quality of the institutional environment is transformed into a quality assessment of regulatory policy - predicting of its consequences and selection of the most optimal variant of realization.

\section{Modern state of the institutional environment of small and medium-sized enterprises in Ukraine}

The issue of a national institutional environment's quality and its impact on the functioning of the economy has a complex integral character. Assessment of the quality of the national institutional environment by using existing indexes is made possible because each of the indexes valuation techniques comprises a unit that assesses the quality of institutions from the standpoint of developers of indexes. In our opinion, to assess the quality of national institutional environment, it is possible to use such subindexes within the specified index assessment systems (Tab. 1).

Table 1

\section{Assessment of the quality of institutional environment in the main international corporative index systems}

\begin{tabular}{|c|l|l|}
\hline № & \multicolumn{1}{|c|}{ Index } & \multicolumn{1}{|c|}{$\begin{array}{c}\text { Sub-index for assessing } \\
\text { the quality of institutional } \\
\text { environment }\end{array}$} \\
\hline 1. & $\begin{array}{l}\text { The Global Competitiveness } \\
\text { Index }\end{array}$ & Institutions \\
\hline 2. & $\begin{array}{l}\text { The IMD World } \\
\text { Competitiveness Yearbook }\end{array}$ & Effectiveness of government \\
\hline 3. & Index of Economic Freedom & All sub-indexes \\
\hline 4. & Doing Business & All sub-indexes \\
\hline 5. & $\begin{array}{l}\text { The Global Enabling Trade } \\
\text { Index }\end{array}$ & Business environment \\
\hline
\end{tabular}

Such index systems as the "Index of Economic Freedom" and "Doing Business" by themselves are the models of national institutional environment, so their indicators can be fully used as indicators of the quality of institutional environment. In the other three systems, only some sections reflect the state of institutions.

We have assessed the national institutional environment with the help of the most popular in the world international index evaluation system - The Global Competitiveness Index (Stroiko, Dusheyko, 2016). Components' data of the Global Competitiveness Index during 2006-2015 were analyzed by the pillars and ranked according to the average values. It was found that the indicators of Ukraine have the lowest rating of the institutions (in fact - the quality of national environment) among other pillars of the Global Competitiveness Index indicators. Ukrainian national economic system on the classification of the
Global Competitiveness Index is on the second stage of development - are efficiency-driven. At the same time in 2006 it answered the first - the lowest level - a factor-driven economy. The third stage of economic development innovation-driven economy is the highest according to the method of determining the Global Competitiveness Index. In addition to these three main steps in the method of the Global Competitiveness Index it is provides two intermediate stage - from the first to the second - " $1-2$ ", and from the second to the third ("2-3"). Ukraine is in a transitional stage "1-2" in 2010-2011. It was found that the maximum value of the index 3,3 of pillar "Institutes" for Ukraine, our institutional environment tends to be the lower boundary of this index.

Modern practical economic achievements of the international comparative studies are the index assessments of the state of national economies. One of the first among them - the Global Competitiveness Index, which is calculated by the World Economic Forum since 1979. Using the first of its 12 pillars, «Institutions», it is possible to assess the quality of the national institutional environment of countries covered with investigations.

Analysis of the Global Competitiveness Index data for Ukraine for 2006-2015 indicates that the degree of development of the national institutional environment receives the lowest scores compared with other pillars of indicators for Ukraine - on the average for the analyzed period the pillar "Institutions" received 3,1 points out of 7 possible.

The largest sub-indexes on deviations are identified by analysis of variance, reflecting such phenomena in the modern Ukrainian economy as increasing the potential threats of violence to the business (sub-indexes 1.13 and 1.14).

Even with the sharp decline in 2014-2015 of subindexes related to potential threats of violent interventions for businesses, according to the average values at the first places of institutional environment factors are these indexes and sub-indexes, reflecting the high level of corporate governance, accounting and transparency of public policy. Three sub-indexes with the lowest value are the 1.06 "Independence of the Judiciary", 1.08 "Inefficient Government Expenditures", 1.04 "Public Trust in Politicians".

Thus, the quality of Ukrainian institutional environment on evaluating the Global Competitiveness Index is very low and requires a systematic increase. Values of unit "Institutions" of the Global Competitiveness Index should act as a guideline for development and implementation of state economic policy.

\section{Regulatory policy and small and medium-sized business}

Entrepreneurship is a fundamentally important signed category of well-being and development of society. It forms a socio-economic basis of expanded social reproduction, 
which is confirmed by the experience of successful economic organization of developed countries. The share of small and medium-sized enterprises in the GDP of developed countries reaches $60 \%$. Communities with a conscious attitude towards the role of entrepreneurship in creation of national wealth and the formation of a prosperous middle class have accumulated experience in promoting its development by conducting appropriate economic policy. The most important component of an effective policy to promote entrepreneurship is a regulatory policy, which is institutional in its content.

An important direction of investigations to improve the development and conducting mechanism of the regulatory policy is the concept of institutional environment, which combines the concepts of institution, institutional agreements and transaction costs. This concept serves, in fact, as a modeling of such broad complex concepts as "business climate", "environment for business development", "business environment" and the other related to an integral assessment of the ability of national regulatory system to ensure support and development of entrepreneurship. State regulatory policy is a way to improve relations and enhance the efficiency of the institutions and for it the institutional environment serves as direct object of impact. A model of institutional environment allows determining of the regulatory policy as a policy that changes elements of institutional environment institutions, displays in changes of transaction costs.

Speaking about the normative and practical tasks of the institutional environment, the attention should be paid to the work of Russian researchers Kondratova N.V., Garipova N.I. (Kondratova, Garipova, 2013), who in the result of the analysis of institutional and economic relations identified three main tasks of institutional environment, which solving ensure the effective development of the economic system, namely:

1. Improvement of existing and formation of new relations in the activities of institutions.

2. Improving the efficiency of the institutions' activities.

3. Achievement of positive qualitative changes in the economic and social structure of the country and regions.

While agreeing with this approach, it should be noted that if the state apparatus consciously aims to enhance the socioeconomic role of entrepreneurship through the creation of favorable conditions for its functioning, regulatory policy is the way to implement this aim; effectiveness criterion of this policy is to improve the quality of the national institutional environment that is measured by reduction of transaction costs of entrepreneurship subjects.

All stated above allows describing the mechanism of regulatory policy in the field of entrepreneurship as a logical order. Measures of regulatory policy influence the quality of institutional environment that leads to the change in transaction costs' value related to its use. Changes in entrepreneurs' transaction costs affect their socio-economic effectiveness.
An important socio-economic role of entrepreneurship should be supported by effective public policy on its support and development. Institutional economic analysis provides possibilities for qualitative study of entrepreneurship's problems, development and implementation of regulatory policy, the definition of criteria for its effectiveness. Using a system model of the institutional environment and the principle of methodological individualism allows considering the economic cooperation of representatives of entrepreneurship and government.

\section{The concept of transformation of the national institutional environment}

If the object of regulatory policy is the institutional environment, and the aim of this policy is to improve it, its most important economic characteristics should be considered. Firstly, the institutional environment is seen as a public good with its two main features:

1) nonexclusion - it is impossible to exclude individuals who are parties in the institutional arrangements from the circle of consumption of institutional environment;

2) non-competitiveness in consumption - the use of institutional environment by one of the subjects of the process does not limit the possibilities of other on the conclusion of the institutional arrangements.

A deep examination of institutional environment as a separate public benefit involves a wide range of issues of society demands for its quality, conditions of its modernization, financing, accounting principles.

Second, the institutional environment manifests itself as capital goods - goods whose use in the current period results in the production of other goods in the future. In the process of prolonged use of institutional environment society receives the results of economic activity. As a capital benefit, institutional environment needs investment expenses on its improving and should be amortized.

Third, the institutional environment is an intangible asset - institutions as a set of business rules, do not have a physical embodiment, the value of their use is determined by their quality.

It is obvious that ineffective institutional environment leads to the systemic open and concealed socio-economic losses and corruption. Thus a consideration of ways of creation the effective institutional environment for business as whole and small and medium-sized enterprises in particular is a critical question of nation's preservation and development on the global economic stage.

It is just the creation of qualitative institutional environment for business as whole and subjects of entrepreneurship in particular that should be the main task of state economic policy, which has for an object its economic development. We present a schematic model of the modern institutional environment (Fig. 1).

The institutional environment on this scheme is bordered by rectangle, which contains formal (black balls) and informal (white balls) institutions. In accordance 
with rules of methodological individualism, subjects of institutional economic relations are individuals (anthropomorphous figures on the scheme). The subjects implement among themselves institutional agreements, which are shown by lines ("tracks"). These "tracks" are necessarily go through formal and informal institutions. Conclusion of institutional agreements is a choice among institutional alternatives, discrete choice and transaction performance. Some institutions (both formal and informal) can be not involved into conclusion of institutional agreements, thus it is the question of institutions market subjects' possibility to choose institutions for interaction. Subjects can conclude institutional agreements within the framework of company or state (hierarchies of institutions with certain cruelty) or within the framework of market (relatively soft institution).

Use of transactions allows looking into the economic nature of market, company, state; in neoclassical modeling it looks as black boxes with ins and outs. For example, bipartite market transaction of purchase and sale of consignment between two firms in the institutional environment can be presented as an aggregate of transactions with the use of institutions.

It should be noted that such decomposition in many ways approximates an economic theory to theory and practice of business process management (BPM). In accordance with this approach, all operation of company is considered as an aggregate of business processes, each of which serves as management unit and is subject to hierarchical decomposition to the lowest level of indivisible processes. Orders of business processes, i.e. rules of their performance and management, are used for BPM. In fact, at defined level performed business processes became internal for the company transactions, each of which can be assessed with relation to costs of its performance. In accordance with that, company management effectiveness from the point of view of business processes depends on quality of business processes and orders of their performance. There are two transformations to be distinguished from the standpoint of business processes consideration - physical object manipulation and transactions.

Institutional environment is a background, on which institutional agreements at the level of all economy are taken place; institutions serve as orders. At the same time the institutional approach obliterates distinctions between market, enterprises and state and describes all economic interaction between individuals as a sequence of transactions. Every action of state through the institutional prism looks as establishment or abolition of a formal institution - mandatory rule with an external coercion to its execution.

In the institutional environment (which is exogenousspecified in this model) a conclusion of institutional agreements is taken place as a result of subjects' choice of institutional alternatives in the market of institutions. At the same time this market consists of formalized in the rules of law institutions as well as unformalized. An implemented institutional agreement (use of the chosen institution) is actually a transaction (from lat. transactio concordance, agreement).

Selection of institution (model of behavior, implementation of agreement) is occurred on the basis of subject' (individuals) assessment of comparative advantages of one or another institution use, because the use of each institute is accompanied by time expenditure of individual as well as possible money expenditure. The choice among behavior alternatives of subjects of economic process is a subject to economic evaluation that leads to appearance of transaction costs idea. That is, transaction costs are the way of economic evaluation of institutional agreements, transactions.

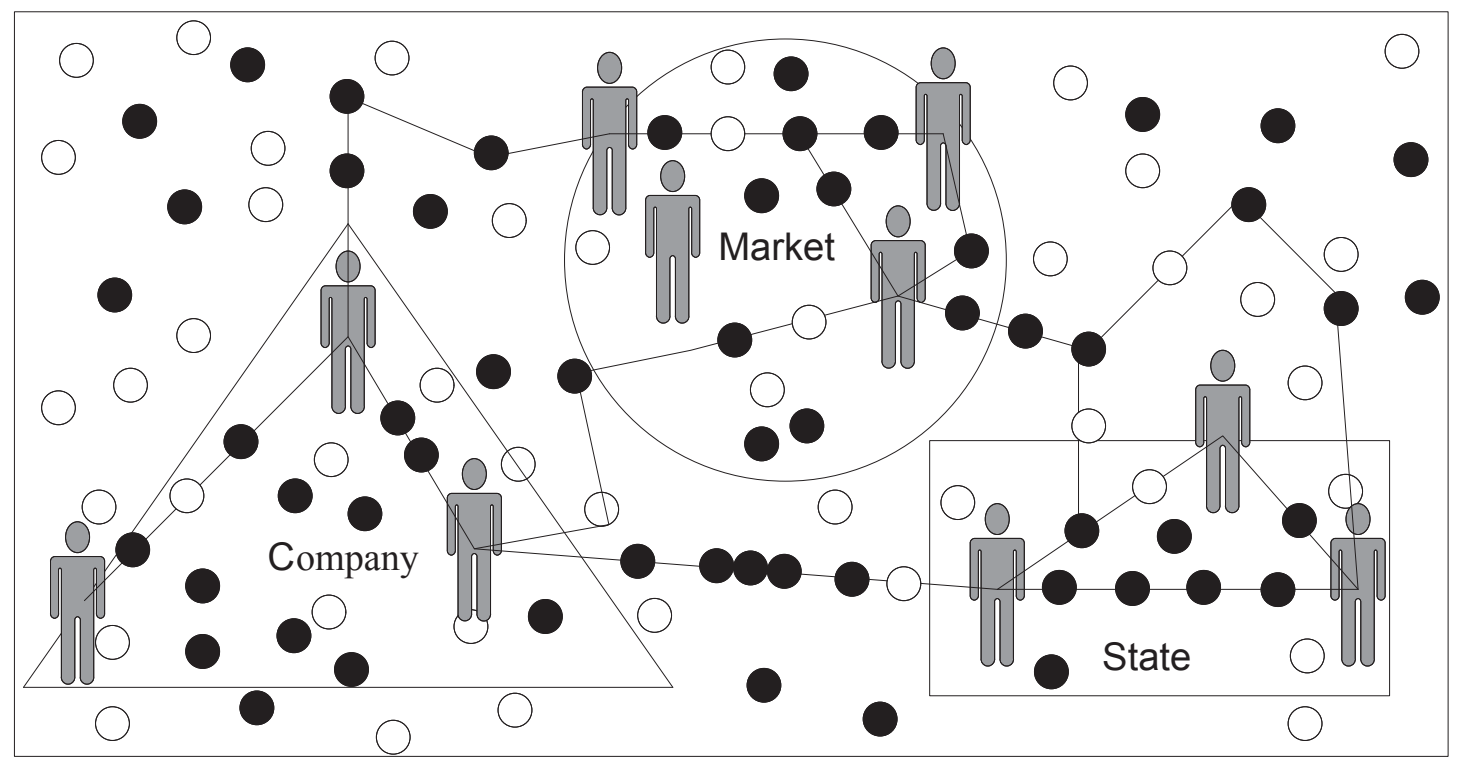

Fig. 1. Model of institutional environment (developed by author) 
Transaction costs are exactly that necessary economic element that brings institution out to the area of essentially economic research. Institutions, which are the brainchild of sociology, become an element of economic analysis only on the assumption of assessment of transaction costs, related with their use. The assessment of transaction costs of institution market use lies in the ground of quality assessment of institutional environment. The higher quality of institutional environment is, the cheaper its use by subjects of economic interaction is. Question of quality of institutional environment of entrepreneurship institutions' market in economic research adds up to assessment and comparison of transaction costs that accompany use of the market.

\section{Conclusions}

An important socio-economic role of small and medium-sized enterprises must be confirmed by effective public policy with its support and development. Institutional economic analysis provides the possibilities of qualitative research of problems of small and mediumsized enterprises, developments and introduction of regulatory police, determining of the criteria of its efficiency. The use of system model of institutional environment and principle of methodological individualism allows considering the economic interaction between representatives of small and mediumsized enterprises and state. An increase of institutional environment quality is the main task of regulatory policy. The quality of Ukrainian institutional environment by the criteria of international rating Doing Business in comparison with the leading countries during 20072013 not exceeded $27 \%$. A criterion of regulatory policy effectiveness in the model of institutional environment is a cheapening of institutional agreements, i.e. transaction costs decrease that leads to increase of socio-economic effectiveness of small and medium-sized enterprises.

\section{References}

Uilyamson, O. (1996). Ekonomicheskie institutyi kapitalizma. Firmyi, ryinki, «otnoshencheskaya» kontraktatsiya. $\mathrm{SPb}$ : : Lenizdat, $702 \mathrm{p}$.

Nort, D. (2000). Institutsiyi, institutsiyna zmina ta funktsionuvannya ekonomiki. - K.: Osnovi, 198 p.

Auzan, A.A. (2005). Institutsionalnaya ekonomika: Novaya institutsionalnaya ekonomicheskaya teoriya. M.: Infa-M., 333 p.

Stroiko T. \& Dusheyko D. (2016) Quality rating of Ukrainian institutional environment in the system of the Global Competitiveness Index. Ukrainian Journal Ekonomist, 2016 (5): 42-45.

The Global Competitiveness Report 2014-2015. Full Data Edition. World Economic Forum, Geneva, 2014. Retrieved from: http://www3.weforum.org/docs/WEF_GlobalCompetitivenessReport_2014-15.pdf

Kondratov, M.V., Garipov, R.I. (2013). Teoreticheskie podhodyi k ponyatiyu «institutsionalnaya sreda». Fundamentalnyie issledovaniya, № 11, part 9, p. 1908-1911.

\section{Татьяна СТРОЙКО, Дмитрий ДУШЕЙКО \\ КОНЦЕПТ ТРАНСФОРМАЦИИ НАЦИОНАЛЬНОЙ ИНСТИТУЦИОНАЛЬНОЙ СРЕДЫ МАЛОГО И СРЕДНЕГО ПРЕДПРИНИМАТЕЛЬСТВА}

Аннотация. Целью работы является попытка обосновать концепт трансформации национальной институциональной среды как предпосылки формирования зажиточного класса малого и среднего предпринимательства. Институциональный анализ рассматривает взаимодействие на уровне индивидуумов, а рыночную сделку делит на трансакции (институциональные соглашения), оценивая их стоимость с помощью трансакционных издержек. Проведенная нами систематизация определения сводят институциональную среду к совокупности норм, правил, согласований, правил игры. Для оценки качества институциональной среды на макроуровне нами использовались прямые показатели его оценки - индексы качества в международных рейтингах и показатели специализированных институциональных исследований. Практическое значение. В результате качество украинской институциональной среды по оценке Индекса глобальной конкурентоспособности является крайне низкой и требует системного повышения. Значения показателей блока «Институты» Индекса глобальной конкурентоспособности должны выступать ориентиром при разработке и внедрении государственной экономической политики. Важным направлением исследований по совершенствованию механизма разработки и проведения регуляторной политики выступает концепция институциональной среды, которая объединяет в себе понятия института, институциональных соглашений, трансакционных издержек. Модель институциональной среды позволяет определить регуляторную политику как политику, которая меняет элементы институциональной среды - институты, отображается в изменениях трансакционных издержек. Обосновано, что государственный аппарат осознанно ставит своей целью повышение социально-экономической роли предпринимательства через создание благоприятных условий его функционирования, то способом реализации такой цели 
выступает регуляторная политика, критерием эффективности которой является повышение качества национальной институциональной среды, что измеряется снижением трансакционных издержек субъектов предпринимательства. Вышеизложенное позволило описать механизм регуляторной политики в сфере предпринимательства как логическую последовательность. Мероприятия регуляторной политики влияют на качество институциональной среды, что приводит к изменению величины трансакционных издержек, связанных с его использованием. Изменения в трансакционных расходах предпринимателей влияют на его социально-экономическую эффективность. Разработано схематическую модель современной институциональной среды. Согласно правила методологического индивидуализма, субъектами институциональных экономических отношений выступают отдельные лица, индивидуумы. Субъекты осуществляют между собой шаблонные институциональные соглашения, которые представлены линиями. Эти «дорожки» обязательно проходят через формальные и неформальные институты. Заключение институциональных соглашений - выбор между институциональными альтернативами, дискретный выбор, осуществления трансакций. Некоторые институты (как формальные, так и неформальные), могут быть не задействованными в заключении институциональных соглашений, поэтому речь идет о рынке институтов - возможность субъектов выбирать институты для взаимодействия. Субъекты могут заключать институциональные соглашения в рамках фирмы или государства (иерархии институтов с определенной жесткостью) или в рамках рынка (относительно мягкие институты). Важная социально-экономическая роль малого и среднего предпринимательства должно подтверждаться эффективной государственной политикой по его поддержке и развитию. Институциональный экономический анализ обеспечивает возможности качественного изучения проблематики малого и среднего предпринимательства, разработки и реализации регуляторной политики, определение критериев ее эффективности. Использование системной модели институциональной среды и принципа методологического индивидуализма позволяет рассмотреть экономическое взаимодействие представителей малого и среднего предпринимательства и государства. Повышение качества институциональной среды - главная задача регуляторной политики. Качество украинской институциональной среды по критериям международного рейтинга Doing Business по сравнению с передовыми странами за 2007-2013 гг. не превышала 27\%. Критерием эффективности регуляторной политики в модели институциональной среды выступает удешевления институциональных соглашений, то есть снижение трансакционных издержек, что приводит к повышению социально-экономической эффективности малого и среднего предпринимательства. 